\title{
Use of Benthic Algae and Bryophytes for Monitoring Rivers
}

\author{
Brian A. Whitton* \\ School of Biological and Biomedical Sciences, Durham University, Durham DHI 3LE, UK
}

\begin{abstract}
Many countries have adopted a single, well-described approach to the use of phototrophs for monitoring river water quality, which involves the use of indices related to diatom composition at a site. Increasingly these indices have focussed on assessing ambient phosphate concentration. However, there is a wide range of other methods which can provide additional information to make up for any weaknesses in the standard method. Some of these methods are reviewed briefly here. They can be useful, for instance, when considering temporal and spatial variability in phosphate concentration at a particular site and providing much more insight on heavy metal or pesticide pollution than revealed by routine water analysis.
\end{abstract}

Key Words: Monitoring program, river, benthic algae, bryophyte, periphyton index, diatom, phosphate, surface phosphatase, heavy metal, skilled taxonomist

\section{INTRODUCTION}

Phototrophs have been used in many ways for monitoring river water and there is a huge literature on the topic, but the relative advantages of the various methods are not always made clear. Even if the National Aquatic Ecological Monitoring Program (NAEMP) for Korea relies largely on one diatom-based method, much as described by Martyn Kelly (this volume) for the UK and some other countries in the European Union, it is important to have a broad perspective on other approaches. The aim of the present short review is to do this for methods involving benthic algae and bryophytes. Rooted vascular plants have also often been used, but detailed interpretation of the results requires understanding of the relative importance of sediments and the water column for each species. The review by Stevenson et al. (2010) provides a more detailed account of methods based on diatoms and the study by Stancheva et al. (2010) mentions methods for non-diatom benthic algae, together with an account of their own method based on algal biovolume and species number.

\section{USE OF INDICES}

Early studies on river water quality in Europe and North America were made by individual researchers developing methods for a particular river or region. These often involved simple estimates of the biomass of organisms such as Cladophora, the ecology of which was understood quite well. Although this approach is now seldom part of the standard monitoring in the original regions, similar approaches are currently adopted widely in subtropical countries such as Brazil and India.

Methods requiring much more detailed taxonomic information started to be developed in countries of eastern and central Europe in the 1960s, especially developments

\section{Open Access http://dx.doi.org/10.5141/ecoenv.2013.012}

This is an Open Access article distributed under the terms of the Creative Commons Attribution Non-Commercial License (http://creativecommons. org/licenses/by-nc/3.0/) which permits unrestricted non-commercial use distribution, and reproduction in any medium, provided the original work is properly cited.
Received 04 March 2013, Accepted 17 March 2013

*Corresponding Author

E-mail: b.a.whitton@durham.ac.uk

Tel: +44-191-3867504 
of the Saprobien System (a German term) suggested as long ago as 1909 by Kolkwitz and Marsson for monitoring organic pollution in rivers. Subsequent developments required detailed information about how each species responded to its environment to provide saprobic index values. Such information came largely from specialists, who had obtained their opinions by observing correlations between occurrence of a species and a particular environment. Descy (1979) suggested that indices based on diatoms alone can be used for routine comparisons of water quality. Since then, increasing care has been taken to make the approach more quantitative, standardize it for surveys in different regions and make it reliable enough for long-term comparisons and use in legal issues. However, the indicator values required for individual species are still based on correlations with environmental variables. Nowadays most indices are calibrated against a phosphate gradient; if the water contains a range of other factors with a marked impact on the diatoms, the index value is simply an indication of the difference of the site from pristine conditions. Much more could be interpreted about the environment of a sample, if more were known about the ecology of each taxon included in an index,. It is therefore important to retain quantitative data about individual species, not just index values, if the information is to be used for monitoring long-term changes. Even if slides of diatom samples are retained, it seems unlikely that they will all rechecked for individual species counts at some future time.

Some individual researchers and the monitoring programs in a few countries still use the full or a wide range of taxa in periphyton (including cyanobacteria) for routine monitoring, such as Schneider and Lindstrøm (2009, 2011) in Norway. There are several reasons why this approach is adopted there and in some other regions of northern Europe. There are sufficient skilled taxonomists able to identify the full range of phototrophs, something not always true in other countries. Phosphate concentrations are often much lower than in other regions of Europe, as shown by the fact that the majority of samples assessed by Schneider and Lindstrøm (2011) were in the range 1-30 $\mu \mathrm{L} \mathrm{L}^{-1}$ total phosphate-P, while most of the others were still $<100 \mu \mathrm{g} \mathrm{L}^{-1}$. In contrast, a large-scale survey of rivers in eastern UK (Whitton and Neal 2011) reported that the median values for total (filterable) $\mathrm{P}$ were above $100 \mu \mathrm{g} \mathrm{L}^{-1}$ at 6 out of 10 midstream sites and at all downstream sites.

The indicator lists produced by Rott et al. (1999), which were largely based on studies in Austria, include diatoms as well as cyanobacteria and other eukaryotic algae. Rott's indicator values for diatoms are used for routine monitoring by several countries in central Europe, including Austria, Germany and Poland. In a detailed classification of rivers in Germany according to the Water Framework Directive (European Union 2000) cyanobacteria, eukaryotic algae and macrophytes were all involved (Schaumberg et al. 2004). However, Schneider and Lindstrøm (2011) pointed out that many benthic algae common in Norwegian waters are not included in the indicator list of Rott et al. One explanation for this is the predominance of soft waters in Norway and hard waters in central Europe, but other factors are probably also important. A factor (not discussed fully by the authors) is that much of the P may be organic, especially where water drains from peatlands. In northern England organic P concentrations in such environments can vary markedly during the year (Whitton 2012), typically with the highest concentrations in early spring. There do not seem to be critical comparisons of floristic data to indicate whether the composition of any particular major taxonomic group is likely to differ between regions more than that of another.

The Periphyton Index of Trophic status (PIT) developed by Schneider and Lindstrøm (2011) is based on presence/ absence of the full range of cyanobacteria (76 taxa) and eukaryotic algae other than diatoms (73 taxa). Theoretically one might expect the number of species at a site to be similar whatever the time of year it was sampled, though a few species might sometimes be inoculated from upstream, but not maintain a permanent population. If sampling is sufficiently thorough, there should be few differences in the PIT value during the year. However, Lindstrøm et al. (2004) commented that the algal flora in Norwegian rivers is typically best developed in autumn, though this seems to refer to abundance rather than species diversity. Nevertheless Schneider and Lindstrøm (2011) excluded samples between December and May, though they later concluded there was no significant difference between summer and winter samples for the 12 sites in their dataset which had been sampled in both seasons within one year of each other. All of this suggests that indices based on presence/absence are excellent for broad surveys involving a large number of sites, but of little use for following small temporal changes at one site. In an earlier account, the same authors (Schneider and Lindstrøm 2009) also produced an Acidification Index for Norwegian rivers based on eukaryotic algae and cyanobacteria, with decreasing $\mathrm{pH}$ having an especially marked effect on cyanobacterial diversity.

Several other problems need to be considered when sampling to collect information to provides index values. 
One is the degree of spatial heterogeneity at a site. Provided there are plenty of suitable surfaces for periphyton development, typically the procedure suited for lowland nutrient-rich sites is straightforward, such as the use of five boulders for sampling diatoms. However, further upstream the author has observed that algal communities are more heterogeneous, if the full range of phyla are included, and thorough studies are needed to establish what is the suitable procedure for particular sites. The skill of the person collecting samples is especially important here, because someone with experience may notice scattered colonies of a colonial diatom such as Didymo- sphenia geminata, which can easily be overlooked by those without much understanding about algae in the field.

Routine diatom-based monitoring usually neglects the fact that live and dead cells are included in samples, although the problem has been studied by a number of authors. Gillett et al. $(2009,2011)$ have looked at this in detail for streams and rivers in western USA, with the latter paper including a short review of previous literature. A study (Gillett et al., 20110 of 587 sites) found that the median percentage of live diatoms (PLD) was low (34.5\%) and highly variable, with responses to human interference differing between three major ecoregions. Provided this was taken into account and care was taken to ensure reference sites represent natural conditions, it was concluded that PLD is a potential metric for monitoring human disturbance of streams.

\section{ARTIFICIAL SUBSTRATES}

Artificial substrates for periphyton growth, usually glass slides, have been used in many studies aimed at answering particular queries, though seldom for long-term monitoring. Butcher et al. (1937) were among the first to conduct a well-designed study to compare the algal flora at different sites, with glass slides held on well-staked holders in the fast-flowing River Tees, UK; this river experienced large differences in the degree of organic pollution on passing downstream. Subsequently a variety of methods have been adopted to hold slides or other substrates, this being much easier to arrange in rivers where current speeds are less rapid. Plastic buckets equipped with floaters have been immersed in the water column at a standard depth and everything tied to the river bank to investigate the effects of Cd and $\mathrm{Zn}$ (Gold et al. 2002), pesticides (Morin et al. 2009) and reciprocal transfers between clean and highly polluted rivers (Duong et al. 2012). Although glass slides have provided useful insight in these studies, they tend to produce a less diverse assemblage than some other substrata (Cattaneo). As artificial substrata do not assess what is actually found at a site, their use may not fit legislative requirements for monitoring.

The rate with which the initial stages of colonization occurs can be influenced by many factors, such as whether or not there is already any sort of biofilm present, even if it lacks diatoms. Hoagland et al. (1982) found that a mature biofilm could develop in 2 to 4 weeks, but other authors have reported longer. More recent studies have involved transplants between sites (Iserentant and Blancke 1986, Ivorra et al. 1999, Tolcach and Gomez 2002) or modelled effects (response of the Eastern Canadian Diatom Index) under simulated conditions (Lacoursière et al. 2011). These and other studies show that periphytic algal assemblages react rapidly to degradation of water quality, but less rapidly to its improvement. Simulated changes in water quality led to changes in diatom assemblage structure in oligotrophic, mesotrophic and eutrophic rivers within 1, 2 and 5 weeks, respectively (Lavoie et al. 2008).

The detailed translocation studies of Ivorra et al. (1999) demonstrated the value of this approach for investigating pollution by heavy metals. Their project involved not only the response of the diatom community structure, but also effects on individual cells such as size, growth form and morphological abnormalities. Metal contamination proved to be a strong driver of community structure and enabled the recognition of tolerant species like Cocconeis placentula var. euglypta, Eolimna minima, Fragilaria gracilis, Nitzschia sociabilis, Pinnularia parvulissima and Surirella angusta.

\section{BIOMASS}

Because large growths of benthic algae, especially Cladophora, cause problems in many rivers, attempts have been made to develop standard methods for quantifying algal biomass, usually estimated as chlorophyll $a$ (Kelly and Whitton 1998). However, heterogeneity at sites and problems with sampling have made this impractical for large-scale monitoring programs. In addition, the relationship between standard crop and nutrient concentrations is often less obvious than for river and lake phytoplankton. Nevertheless the approach has proved useful in studies of changes down particular rivers, such as River Oria, Spain (Sabater et al. 2000) and Clark Fork River, USA (Suplee et al. 2012). Simplified methods, such as percentage cover of macroscopically obvious taxa, have also been used in a number of studies, sometimes combined with 
semi-quantitative estimates for microalgae at the same site (e.g. Pipp and Rott 1996), but again these seem of most use for studies of local regions rather than broad surveys.

\section{ACCUMULATION OF METALS AND PESTICIDES}

Benthic algae and bryophytes have been used in numerous studies as an aid to monitoring heavy metal pollution in rivers (Whitton 2003). The information provides a useful supplement to water chemistry analysis when the ambient metal concentrations are highly variable and when a suspected pollutant has already passed downstream or there is a need to trace where the source of industrial contamination originates. In most cases this has involved analysis of the whole organism or a part such as the shoot apices of a moss. Bryophytes usually accumulate metals to much higher concentrations than algae (Kelly and Whitton 1989), but filamentous algae may respond more rapidly to changing concentrations. Some attempt has been made to standardize methods (Whitton et al. 1991). Although some recent studies have made considerable use of earlier literature (e.g. Gapeeva et al. 2010), many others have been done without the researchers being much aware of what has been done previously. This is in largely because this approach, which was tested widely in Europe in the 1970s and 1980s, is now mainly used in countries such as China with rapidly expanding industrial and mining activity, but without a long tradition of routine monitoring.

Algae occurring at sites influenced by long-term metal pollution usually show clear evidence of being adapted genetically to the ambient metal concentrations, though some taxonomic groups probably evolve more rapidly than others, leading to differences in floristic composition between those sites which have been polluted for only a short time and those polluted by similar metal concentrations over many decades (Whitton and Diaz 1975). Many metal toxicity studies have been conducted on biofilms, so it should be possible to combine routine diatom surveys with metal resistance assays of live diatoms in the same sample, but this has apparently not yet been attempted.

\section{PHYSIOLOGICAL AND MORPHOLOGICAL AP- PROACHES}

Primary production measurements and various types of bioassay have been incorporated into monitoring studies, but are largely excluded from this review. However, brief mention is made of two methods which help distinguish between the relative impostance of combined nitrogen and of phosphate for algae or bryophytes at a site, something which is not routinely available from the present diatom-based methods. Surface phosphatase activity of organisms or assemblages can be used to indicate the extent to which they are P-limited. The practical methods are relatively simple (Whitton et al. 2002, Turner et al. 2003), though it is essential to have a thorough understanding of the underlying science (Whitton et al. 2005), if the results are to be interpreted properly. In addition to the value of the method for surveying upland sites, it can also help find stretches of river bank where lateral drainage from fields leads to local hotspots for phosphate input because of an obvious reduction in surface phosphatase activity.

In less nutrient-rich waters morphological observations on some phototrophs can provide considerable insight to the nutrient regime. The formation of long tapered filaments, often with the development of multicellular hairs, indicates P-limiting conditions in all cyanobacteria and eukaryotic algae so far studied (Whitton 2011). This occurs in many genera of filamentous cyanobacteria (especially Rivulariaceae) and most members of the Chaetophorales in the green algae. Multicellular hairs characterize organisms living in environments which lead to P-limitation for much of the time, but with shorter periods of $\mathrm{P}$ enrichment. The approach is so simple that it should be used to supplement diatom surveys in upland regions, especially if combined with observations on the nitrogen-fixing heterocyst cells.

\section{CONCLUDING COMMENTS}

The incorporation of diatom-based indices in routine monitoring programs has made a valuable contribution to understanding of river quality.and, once staff are trained to a sufficient skill level, it is relatively straightforward and easy to manage. It is most effective in mesotrophic and eutrophic environments. However, there are a wide range of other methods, only some of which have been mentioned here, which can used to deal with particular problems that cannot be answered with the standard diatom methodology. Most of the other methods are straightforward to carry out, but require staff trained to a higher level and who use the method frequently enough to do them well. For most of these methods, the more 
the member of staff knows about the field site, the more useful the subsequent data obtained in the laboratory are likely to prove.

\section{LITERATURE CITED}

Butcher RW, Longwell J, Pentelow FTK. 1937. Survey of the River TeEs. Part III. The Non-Tidal Reaches - Chemical and Biological. Her Majesty's Stationery Office, London. $189 \mathrm{pp}$.

Descy J-P. 1979. A new approach to water quality estimation using diatoms. Nova Hedwigia 64, 305-323.

Duong TT, Coste M, Feurtet-Mazel A, Dang DK, Ho CT, Le TPQ. 2012. Responses and structural recovery of periphytic diatom communities after short-term disturbance in some rivers (Hanoi, Vietnam). J. Appl. Phycol. 24, 1053-1065.

European Union. 2000. Directive 2000/60/EC of the European Parliament and of the Council of 23 October 20000 establishing a framework for Community action in the field of water policy. Official Journal of the European Communities L327: 1-73.

Gapeeva MV, Dolotov AV, Chemeris EV. 2010. Prospects of using mosses (Fontinalis antipyretica Hedw. and Pylaisia polyantha (Hedw.) Bruch et al.) as indicators of environmental contamination with heavy metals. Russian Journal of Ecology 41, 128-131.

Gillett ND, Pan Y, Parker C. 2009. Should only live diatoms be used in the bioassessment of small mountain streams? Hydrobiologia 620, 135-147.

Gillett ND, Pan Y, Manoylov KM, Stevenson RJS. 2011. The role of live diatoms in bioassessment: a large-scale study of Western US streams Hydrobiologia 665, 79-92.

Gold C, Feurtel-Mazel A, Coste M, Boudou A. 2002. Field transfer of periphytic diatom communities to assess short-term structural effects of metals $(\mathrm{Cd}, \mathrm{Zn})$ in rivers. Water Res. 36, 3654-3664.

Hoagland KD, Roemer SC, Rosowski JR. 1982. Colonization and community structure of two periphyton assemblages, with emphasis on the diatoms (Bacillariophyceae). Am. J. Bot. 69, 188-213.

Iserentant R, Blancke D. 1986. A transplantation experiment in running water to measure the response rate of diatoms to changes in water quality. In: Ricard M. (ed.), Proceedings of the 8th International Diatom Symposium, Paris, 1984, 347-354.

Ivorra N, Hettelaar J, Tubbing GMJ, Kraak MHS, Sabater S, Admiraal W. 1999. Translocation of microbenthic algal assemblages used for in situ analysis of metal pollution in rivers. Arch. Environ. Contam. Toxicol. 37, 19-28.

Kelly M, Whitton BA. 1989. Interspecific differences in Zn, $\mathrm{Cd}$ and $\mathrm{Pb}$ accumulation by freshwater algae and bryophytes. Hydrobiologia 175: 1-11.

Kelly MG, Whitton. 1998. Biological monitoring of eutrophication in rivers. Hydrobiologia 384: 55-67

Kolkwitz R, Marsson M. 1909. Ökologie der tierschen Saprobien. Ber. Deutschen Bot. Gesell. 26a, 505-519.

Lacoursière S, Lavoie I, Rodríguez MA, Campeau S. 2011. Modeling the response time of time of diatom assemblages to simulated water quality improvement and degradation in running waters. Can. J. Fish. Aquat. Sci. 68, 487-497.

Lavoie I, Campeau S, Darchambeau F, Cabana G, Dillon PJ. 2008. Are diatoms good integrators of temporal variability in stream water quality? Freshwat. Biol. 53, 827-841.

Morin S, Pesce S, Tlili A, Coste M, Montuelle B. 2010. Recovery potential of periphytic communities in a river impacted by vineyard watershed. Ecol. Indic. 10, 419-426.

Sabater S, Armengol J, Comas E, Sabater F, Urrizalqui I, Urrutia I. 2000. Algal biomass in a disturbed Atlantic river: water quality relationships and environmental implications. Sci. Total Environ. 263, 185-195.

Schneider S. 2011. Impact of calcium and TOC on biological acidification assessment in Norwegian rivers. Sci. Total Environ. 409, 1164-1171.

Schneider S, Lindstrøm E-A. 2009. Bioindication in Norwegian rivers using non-diatomaceous benthic algae: The acidification index periphyton (AIP). Ecological Indicators 9: 1206-1211.

Schneider S, Lindstrøm E-A. 2011. The periphyton index of trophic status PIT: A new eutrophication metric based on non-diatomaceous benthic algae in Nordic rivers. Hydrobiologia 665:143-155.

Stancheva R, Fetscher E, Sheath RG. 2012. A novel quantification method for stream-inhabiting, non-diatom benthic algae, and its application in bioassessment. Hydobiologia 684, 225-139.

Stevenson RJ, Pan Y, Van Dam H. 2010. Assessing environmental conditions in rivers abd strams with diatoms. In: Smol J.P. and Stoermer E.F. The Diatoms. Applications for the Environmental and Earth Sciences. 2nd edn. Cambridge University Press, 57-85.

Suplee MW, Watson V, Dodds WK, Shirley C. 2012. Response of Algal Biomass to Large-Scale Nutrient Controls in the Clark Fork River, Montana, United States. JAWRA 48, 1008-1021.

Tolcach ER, Gomez N. 2002. The effect of translocation of microbenthic communities in a polluted lowland stream. Verh. Int. Verein. Limnol. 28, 254-258. 
Turner BL, Baxter R, Ellwood NTW, Whitton BA. 2003. Seasonal phosphatase activities of mosses from Upper Teesdale, northern England. J. Bryol. 25, 189-200.

Whitton BA. 2003. Use of plants for monitoring heavy metals in freshwaters. In: Ambasht R.S. and Ambasht N.K (eds) Modern Trends in Applied Aquatic Ecology. Kluwer Academic / Plenum Publishers, N.Y. 379 pp., pp. 43-63.

Whitton BA. 2011. Phylum Cyanobacteria (Cyanophyta). In: John D.M., Whitton B.A. and Brook A.J. (eds) The Freshwater Algal Flora of the British Isles. Second Edition. Cambridge University Press, Cambridge 868 pp., 31-158.

Whitton BA. 2012. Changing approaches to monitoring during the period of the 'Use of Algae for Monitoring Rivers' symposia. Hydrobiologia 695, 7-16.

Whitton BA, Al-Shehri AH, Ellwood NTW, Turner BL. 2005. Ecological aspects of phosphatase activity in cyanobacteria, eukaryotic algae and bryophytes. In: Turner B.L., Frossard E. and Baldwin D.S. (eds) Organic Phosphorus in the Environment. Commonwealth Agricultural Bureau, Wallingford, UK 399., pp. 205-241.

Whitton BA, Clegg E, Christmas M, Gemmell JJ, Robinson PJ. 2002. Development of Phosphastase Assay for Monitoring Nutrients in Rivers - Methodology Manual for Measurement of Phosphatase Activity in Mosses and Green Algae. Environment Agency of England and Wales STRE106-E-P 53 pp. (Distributed by WRc, Frankland Road, Swindon, Wilts SN5 8YF)

Whitton BA, Diaz BM. 1980. Chemistry and plants of streams and rivers with elevated zinc. Trace Substances in the Environment 14. 457-463

Whitton BA, Harding JPC, Kelly MK, Say PJ. 1991. Use of Plants to Monitor Heavy Metals in Freshwaters. Standing Committee of Analysts 1990. London, HMSO, 43 pp.

Whitton BA, Neal C. 2011. Organic phosphate in UK rivers and its relevance to algal and bryophyte surveys. Int. J. Limnol. 47, 1-8. 